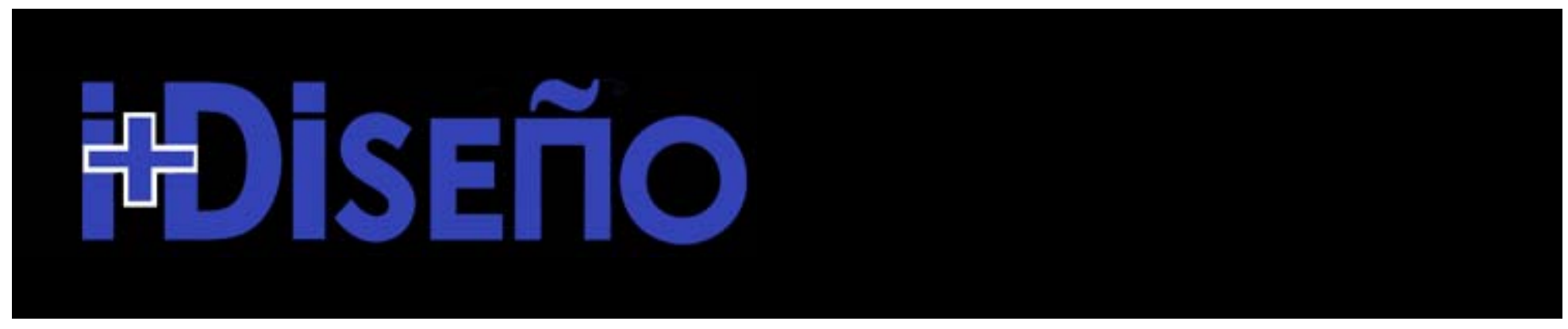

i+Diseño | Vol. 11 | Abril | Año VIII

\title{
La Gráfica del 68
}

Julio César Schara

Universidad Autónoma de Querétaro. México

RECIBIDO: 29.05.2015 / ACEPTADO: 25.06.2015

\section{Resumen}

La presente investigación concentra el análisis de múltiples obras de producción gráfica del Movimiento del 68, realizadas bajo la influencia del Taller de Gráfica Popular y enmarcadas en una estética influida por los movimientos sociales de la época, como una expresión anónima y testimonial que asumía su responsabilidad social, estética y política. La Gráfica del 68, difundía con imágenes visuales la decisión de los jóvenes por la democratización del país y llamar a la participación solidaria; las brigadas de producción establecieron un importante precedente de trabajo colectivo que ilustró una de las acciones más significativas del movimiento estudiantil urbano: la marcha silenciosa.

Palabras clave: movimiento social, México, producción gráfica, libertad de expresión, represión.

\section{La Gráfica del 68}

\section{Abstract}

This research focuses on analyzing multiple works of graphic production of the Movement of 68, performed under the influence of the Taller de Grafica Popular and framed in an aesthetic influenced by the social movements of the time, as an anonymous testimonial expression that assumed its responsibility social, aesthetic and political. The graphical movement of 68, spread with visual images the decision to youth for the democratization of the country and call the joint participation; production brigades established an important precedent for collective work that illustrated one of the most significant actions of urban student movement: the silent march.

Keywords: social movement, Mexico, graphic production, freedom of expression, repression.

La Gráfica del 68, es un acervo histórico visual del primer gran movimiento social y urbano de la Ciudad de México, construido por una serie de carteles, pegas-stickers y volantes, mantas, pancartas y grabados, que fueron elaborados principalmente por los estudiantes de la Escuela Nacional de Artes Plásticas (ENAP), hoy Facultad de Diseño y Arte de la UNAM, en el que también participaron alumnos de la Escuela Nacional de Pintura y Escultura La Esmeralda, el IPN, Chapingo, entre otros. Este material visual fue producido en los Talleres de la Antigua Academia de San Carlos. Gracias a que el grupo MIRA ha hecho una recopilación y publicación de la misma se rescataron estos documentos visuales que representan una ilustración visual de una estética pedagógica, práctica y activa de los lamentables acontecimientos del Movimiento Estudiantil de 1968 que culminaron, con el crimen de Estado del 2 de octubre del mismo año, y que ahora con la desaparición de los Estudiantes Normalistas de Ayotzinapa, de Iguala, Guerrero, se ha convertido, 
hasta el día de hoy en otro crimen de Estado en contra de estudiantes víctimas de la violencia que sufre nuestro país en los últimos años.

Los antecedentes de la Gráfica del 68, se encuentran inscritos en El Taller de Gráfica Popular, cuya fundación se remonta al año de 1937 por los artistas Leopoldo Méndez, Pablo O'Higgins, y Luis Arenal Bastar.
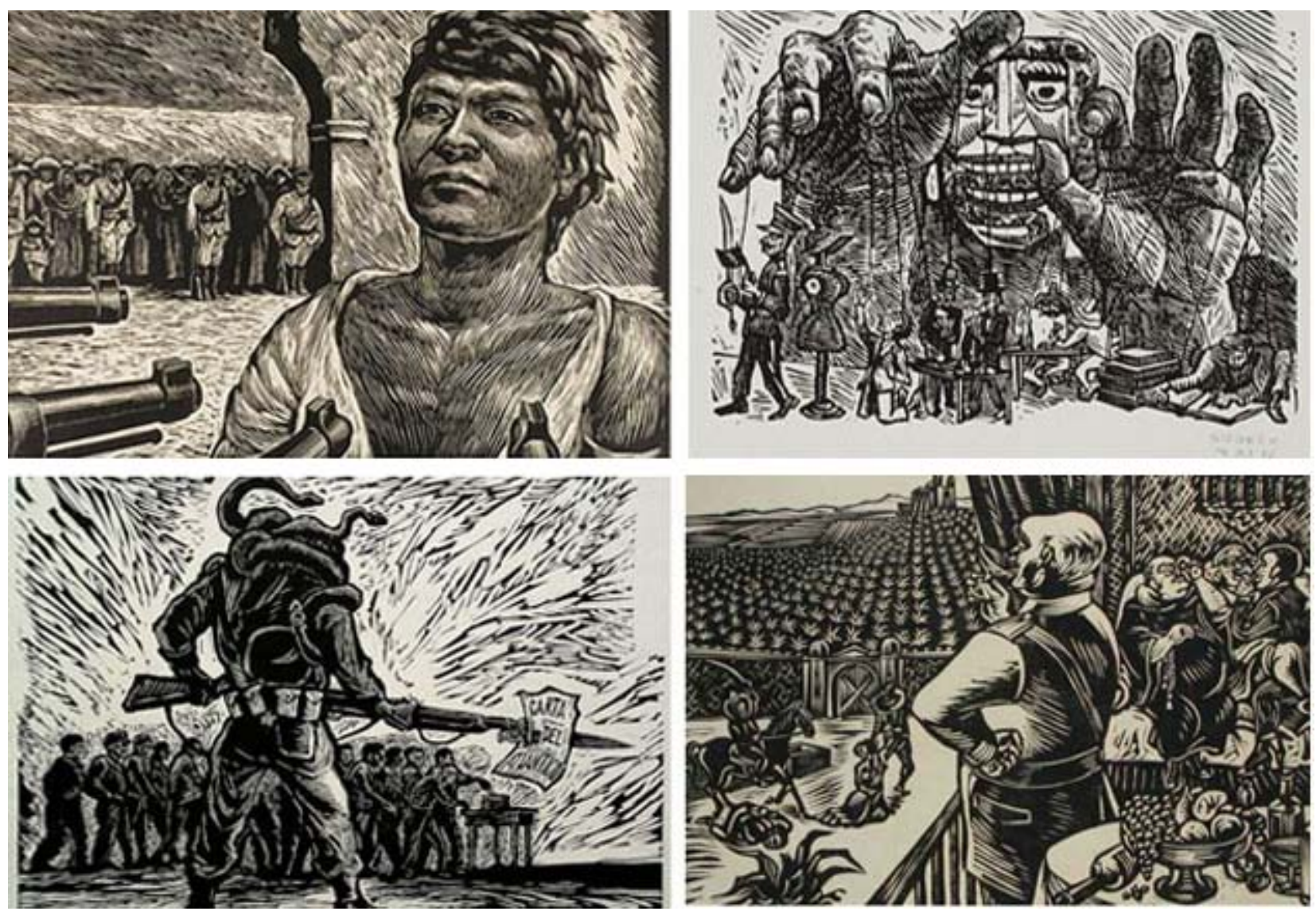

La primera preocupación del colectivo era utilizar el arte para fomentar sus causas sociales revolucionarias. El taller se volvió una base de actividad política y gran desempeño artístico. Además de sus miembros Mexicanos, atrajo muchos artistas extranjeros a colaborar. El taller se fundó tras la disolución de la Liga de Escritores y Artistas Revolucionarios (LEAR), un grupo de artistas que apoyaba las causas de la Revolución Mexicana. Inicialmente llamado el Taller Editorial de Gráfica Popular, sus fundadores tomaron de una rica tradición de Grabado Mexicano, particularmente el legado de José Guadalupe Posada. Durante la presidencia de Lázaro Cárdenas, el trabajo del Taller apoyó las políticas del gobierno, incluida la Expropiación Petrolera.

En 1940, el muralista David Alfara Siqueiros lanzó un ataque armado contra la residencia del exiliado de la Revolución Rusa, León Trotsky. Utilizó el taller como base de operaciones y algunos de los artistas del taller formaron parte del escuadrón. Durante su apogeo, El taller se especializó en grabados en linóleo y en madera. Produjo posters, panfletos, banderas y ediciones de portafolio. El arte apoyaba causas como el antimilitarismo, la unión obrera, y la oposición al fascismo. El arte 
era comúnmente realizado de manera colaborativa. Además, el taller adoptó la práctica anti comercial de no numerar las impresiones. Aún así, vendió impresiones.

Bajo la Marca "La Estampa Mexicana, el Taller de Gráfica Popular vendió posters de héroes y de la cultura mexicana y de movimientos de la izquierda política mexicana e internacional. También dio luz a una nueva generación de "calaveras", una tradición mexicana de caricaturizar políticos y otras figuras populares mediante rimas sencillas y caricaturas de estos personajes reducidos a esqueletos ${ }^{1}$.

La producción de Gráfica Popular es el único antecedente en el arte de México que ha ejercido una estética práctica, esto es una estética que ha ilustrado en forma activa los movimientos sociales de oposición. Por ejemplo La Guerra de Vietnam y, en general, la discriminación, la guerra, la injusticia, el autoritarismo Pinochetista, etcétera. La producción del Taller de Gráfica Popular es realizada hasta la fecha por grabadores y artistas, lo que los separa de la Gráfica del 68, que fue producida principalmente por alumnos y brigadistas de la Academia de San Carlos, y que nunca tuvieron las intenciones de significarlas como obras de arte, sino como propaganda política que si bien buscaba la eficacia, la pregnancia en la imagen que fuera útil al movimiento social urbano de los estudiantes, nunca tuvo intenciones de creación artística.

En 1968 el movimiento social de los estudiantes urbanos se desarrolló y fortaleció en la medida en que los jóvenes de la Ciudad de México participaban como un conjunto de individuos autónomos que discutían y decidían sus formas de participación de manera espontánea, y se organizaban de acuerdo a las necesidades del momento que los brigadistas proponían para llevar a cabo alguna acción: mítines espontáneos que se organizaban en autobuses, plazas, mercados para informar a los ciudadanos de la dinámica contestataria al gobierno y a la solicitud que los estudiantes hacían para el cumplimiento del pliego petitorio. Así fue creciendo la réplica contestataria al gobierno dando lugar a un fenómeno pocas veces vivido por la extensión a la que llegó: la formación de un campo de acción democrático, que el poder político veía con odio creciente multiplicarse en las manifestaciones que eran la expresión viva de la posibilidad de transformación social: capacidad de organización espontánea, capacidad de trabajo voluntario y disciplina sin coacción, rechazo a la corrupción, sensibilidad a las injusticias sociales imperantes, libertad de expresión y rechazo al autoritarismo y al dogmatismo.

La clase dominante y el Estado no veían en el carácter de las demandas del pliego petitorio de los estudiantes el peligro de que se planteara la lucha revolucionaria por el socialismo. El peligro estaba en la organización que requería del ejercicio de la democracia directa, la discusión amplia y el trabajo intensivo, vital para el movimiento, que desempeñaron las brigadas de activistas, eje principal de la dinámica de la subversión estudiantil.

La importancia de la producción gráfica del Movimiento del 68, radica en su carácter testimonial y en las particulares condiciones en que se realizó: estética práctica, pedagógica radical que buscaba reflejar la realidad de la lucha estudiantil ${ }^{2}$ por el cumplimiento del pliego petitorio, así como tener una alternativa de comunicación activa de propaganda política que rompiera el cerco de mentiras, que el Estado, utilizando los medios de comunicación, desprestigiaban el movimiento estudiantil, 
calificándolo entre otros, de una subversión internacional que pretendía desestabilizar el régimen imperante. La Gráfica del 68, difundía con imágenes la decisión de los jóvenes por la democratización del país y llamar a la participación solidaria; las brigadas de producción establecieron un importante precedente de trabajo colectivo que ilustró una de las acciones más significativas del movimiento estudiantil urbano: la marcha silenciosa. El edificio de la antigua Academia de San Carlos se convirtió en un gran taller en el que alumnos, profesores, activistas del IPN, UNAM, Normal, Chapingo y otras escuelas, trabajadores de imprenta, manuales y administrativos, trabajaron sin cesar día y noche para organizar y producir material suficiente, cientos de mantas, miles de pancartas, carteles y grabados para este importante acontecimiento. Durante el movimiento estudiantil la Escuela Nacional de Artes Plásticas, se convirtió en un organismo vivo que asumía su responsabilidad social, estética y política.

\section{La Producción Gráfica}

Los acontecimientos políticos vividos en la Ciudad de México en 1968 dejaron su impronta en una generación. Debido a las repercusiones que tuvieron en diferentes aspectos de la vida de nuestro país, siguen siendo objeto de continuos análisis y estudios. Hemos tratado de contribuir a esta serie de reflexiones ocupándonos del tema de la producción gráfica del movimiento estudiantil, con la idea de presentar y difundir este testimonio gráfico realizado al calor de los hechos. Entre las características de este material destaca la intención de sus productores por construir un lenguaje popular y de crítica social con el fin de transmitir la ideología del movimiento, búsqueda orientada principalmente a lograr la comunicación con la comunidad estudiantil primero, y con los habitantes de la ciudad después.

La Gráfica del 68 tiene un carácter principalmente urbano popular, producto de las condiciones de represión del Estado al movimiento estudiantil, el cual finalmente se aniquila con el genocidio del 2 de octubre de 1968. A diferencia del Taller de Gráfica Popular cuyas imágenes exaltan las luchas campesinas, la historia y tradiciones populares de México.

Sin embargo, la influencia del TGP se puede advertir en la propaganda del Movimiento del 68, que de alguna manera continuó la tradición gráfica de México, por el hecho de responder a las circunstancias de su momento. No olvidemos que en el mes de mayo de ese año los estudiantes franceses habían realizado una jornada similar, cuya producción de propaganda tiene características diferentes, y que fue casi desconocida en nuestro país.

La bayoneta, el gorila, la paloma ensangrentada, el candado en la boca, la madre amordazada (Siqueiros) y otros, fueron los primeros símbolos de denuncia utilizados desde los primeros días de lucha, en contraposición con los símbolos oficiales de la paz, las olimpíadas y la imaginería patriotera. Para esta labor emergente se adoptó la técnica del grabado en linóleum, lo que permitía resultados inmediatos en la difusión, debido a lo sencillo de su factura y el bajo costo de producción; los talleres antes destinados para las prácticas académicas ahora cumplían una función social concreta, se trataba de elaborar imágenes útiles a la lucha, contribuyendo a la misión de contrarrestar la confabulación de los medios masivos de comunicación empeñados en tergiversar la justeza de la rebelión estudiantil. 
Aún con el intenso ritmo de trabajo, apenas si se cubría la demanda de propaganda del movimiento estudiantil, nunca hubo un plan de trabajo preconcebido, solamente se daba respuesta a las necesidades del momento, elaborando constantemente: mantas, pancartas, volantes, pegas (stickers) y carteles. Maestros, estudiantes, trabajadores se solidarizaron con las tareas de esta producción gráfica.

En la medida en que avanzaba la organización general del estudiantado, otras escuelas de arte se sumaban a la lucha; la Escuela Nacional de Pintura y Escultura "La Esmeralda", también se incorporó plenamente aportando su producción de material gráfico. Al mismo tiempo se montaban talleres improvisados en otros centros de estudios. Por las calles, en los camiones, en las escuelas y lugares públicos; las imágenes de Demetrio Vallejo, el Che Guevara, la V de la Victoria, el puño cerrado, etcétera, enriquecían las imágenes visuales de la ciudad, contrarrestando la publicidad de los medios estatales. Ahora es posible ver el valor testimonial de esta producción, en la cual se deja constancia de las demandas del movimiento, así como el control que el Estado tenía sobre los medios masivos de comunicación, las Olimpíadas y los símbolos nacionales tratados en imágenes satíricas, la promoción de los eventos políticos o el recuerdo de acontecimientos trágicos, o de las luchas históricas por la democratización del país.
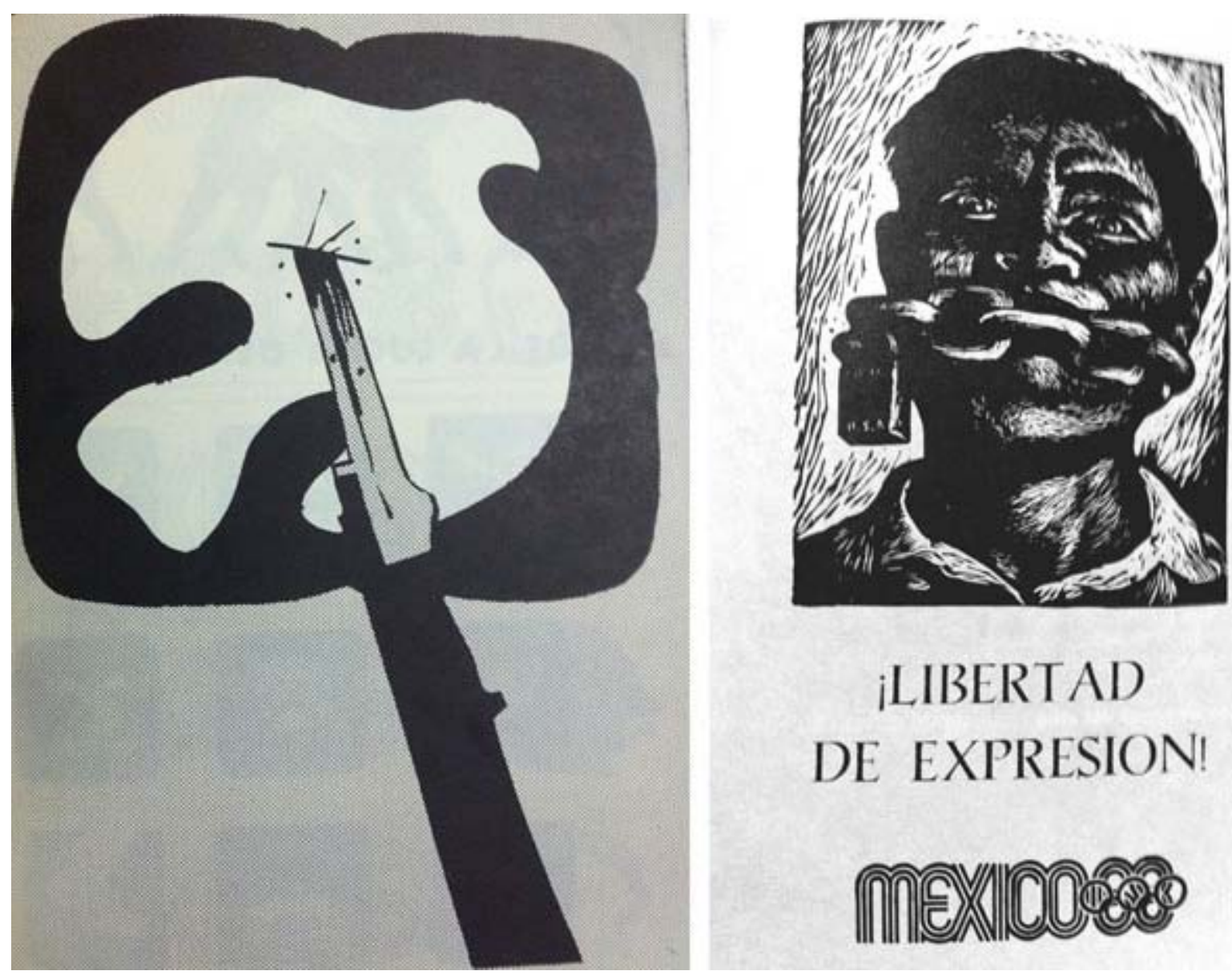

Las prensas, los roles de pruebas y todo tipo de medios de impresión fueron utilizados; en algunas ocasiones un grabado se combinaba con tipografía compuesta a mano o se rayaba directamente sobre el esténcil para mimeógrafo. También se utilizó la serigrafía —aprovechada anteriormente sólo por las empresas publicitarias-y, en menor proporción, se acudió al fotograbado y al offset. 
Ante las condiciones cada vez más difíciles para realizar pintas en las bardas y todo tipo de soportes, debido a la constante represión hacia los brigadistas, varias posibilidades de comunicación fueron puestas en práctica; desde la reproducción de una pega en rollos de papel engomado o el volante-grabado, hasta carteles de diversas dimensiones.

Como se menciona anteriormente, el lenguaje utilizado tiene un carácter estético-didáctico, el tratamiento de la forma, la mayor de las veces es figurativo con rasgos expresionistas en muchos casos. El color negro, el color rojo y el tono de papel de china, o la hoja de periódico, fueron predominantes, dando por resultado un nutrido conjunto de imágenes y símbolos, algunos de ellos vigentes actualmente, y que a la fecha no han sido analizados dentro de su importancia como una estética de la comunicación política urbana.
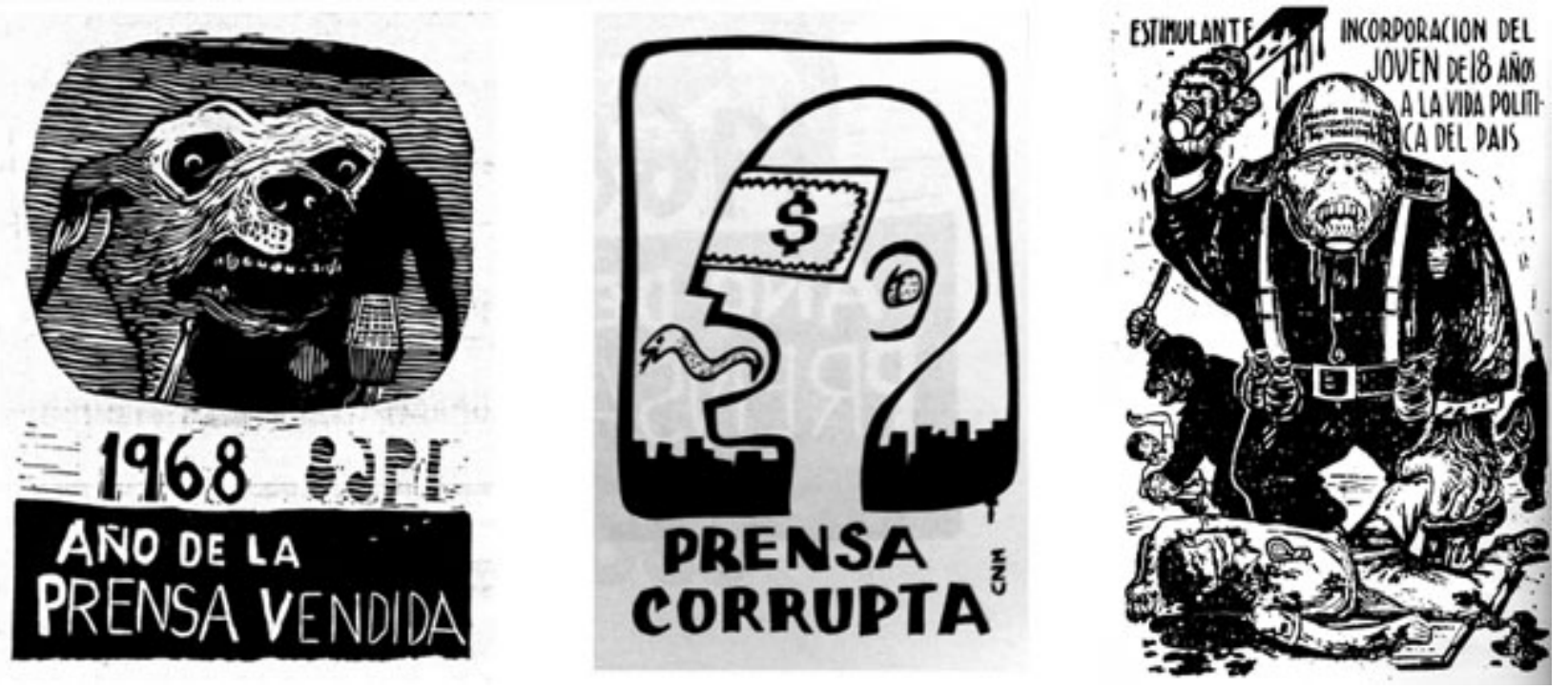

A pesar del recrudecimiento de la violencia represiva contra el estudiantado los habitantes de la ciudad seguían brindando apoyo y la producción de la gráfica no disminuyó. Ya para entonces existía una vasta colección de grabados en los archivos de los talleres con la cual se presentó una exposición en el edificio de San Carlos, evento muy concurrido por la población aledaña, hasta que en uno de los habituales atentados contra los centros de estudios, un grupo paramilitar, destruyó los medios de producción llevándose la colección completa, tal vez única de la gráfica del 68. Se tuvieron que modificar los métodos de trabajo para no suspender la producción; días difíciles y con muchas limitaciones materiales, y que, sin embargo, produjeron un testimonio importante de carácter estético y político para la historia contemporánea de México.

Al año siguiente, en las escuelas de arte siguieron su curso los cuestionamientos a los sistemas de enseñanza, así como el análisis de las vanguardias y posvanguardias del arte universal. Sin embargo, la organización política del estudiantado decayó. Esa gran jornada de solidaridad y combate se desvanecía. Observando esta producción, desde el contexto en que se dio, puede decirse que la Gráfica del 68 rescata la estética práctica y pedagógica de la lucha radical por la democrática del país. Con materiales como la hoja volante, el cartel o el grabado rehicieron el grabado mexicano, desarrollado por el TGP, siendo su obra el antecedente más importante e inmediato de la producción de propaganda gráfica del movimiento urbano estudiantil. 


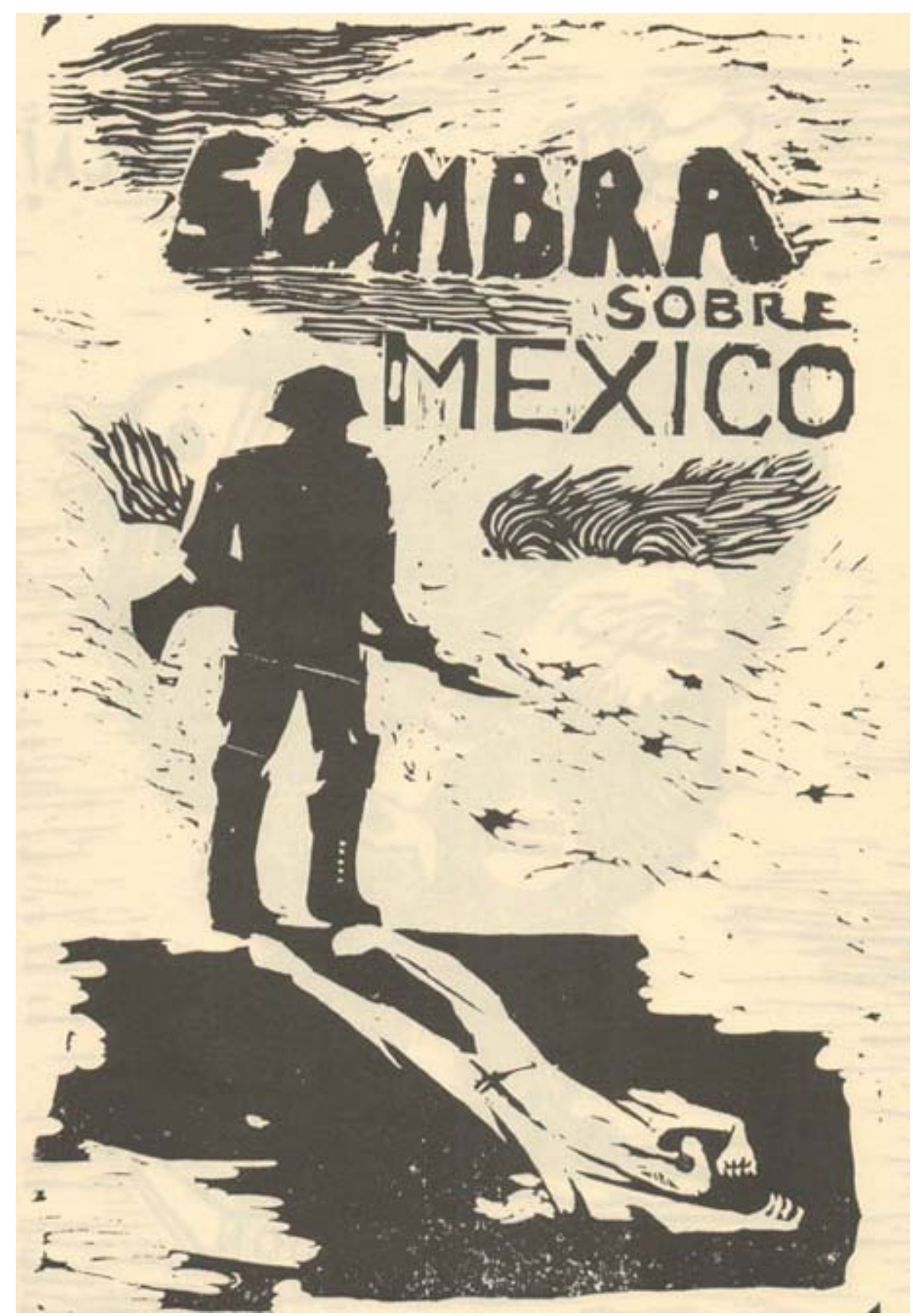

\section{Memorial de Tlatelolco}

Rosario Castellanos

La oscuridad engendra la violencia y la violencia pide oscuridad

para cuajar el crimen.

Por eso el dos de octubre aguardó hasta la noche

para que nadie viera la mano que empuñaba

el arma, sino sólo su efecto de relámpago.

¿Y a esa luz, breve y lívida, quién? ¿Quién es el que mata? ¿Quiénes los que agonizan, los que mueren? ¿Los que huyen sin zapatos? ¿Los que van a caer al pozo de una cárcel? ¿Los que se pudren en el hospital?

¿Los que se quedan mudos, para siempre, de espanto?

¿Quién? ¿Quiénes? Nadie. Al día siguiente, nadie.

La plaza amaneció barrida; los periódicos

dieron como noticia principal

el estado del tiempo. 
Y la televisión, en el radio, en el cine

no hubo ningún cambio de programa,

ningún anuncio intercalado ni un

minuto de silencio en el banquete.

(Pues prosiguió el banquete.)

No busques lo que no hay: huellas, cadáveres

Que todo se le ha dado como ofrenda a una diosa,

A la Devoradora de Excrementos.

No hurgues en los archivos pues nada consta en actas.

Más he aquí que toco una llaga; es mi memoria.

Duele, luego es verdad. Sangre con sangre,

y si la llamo mía traiciono a todos.

Recuerdo, recordamos.

Esta es nuestra manera de ayudar a que amanezca

sobre tantas conciencias mancilladas,

sobre un texto iracundo, sobre una reja abierta,

sobre el rostro amparado tras la máscara.

Recuerdo, recordemos

hasta que la justicia se siente entre nosotros.

1968.

La contestación de los estudiantes al Estado exigía el cumplimiento del pliego petitorio, cuya columna vertebral la sostenía el principio democratizador del país (la derogación de los artículos 145 y 145 bis). La libertad de los presos políticos no por una consigna partidista, sino como conciencia clara de que las detenciones pretéritas eran injustas.

Los jóvenes hicieron una alianza con sus iguales, exaltados gritaban consignas contra la mentira, la hipocresía, y el autoritarismo de Estado, que escondía su fin primordial: la reproducción del capital fundada en la pobreza salarial y la redistribución de la riqueza inequitativa, la corrupción constituida como una legalidad que distaba mucho de garantizar ese principio "tan olvidado y lejano", como decía León Felipe, de la justicia social, real y verdadera.

La Gráfica del 68, no sólo tiene un carácter estético didáctico, es la imagen reflejada, prístina de la realidad en el que los sucesos estudiantiles se desarrollaban. Esa reproducción fiel de la realidad, le otorga también su sentido de estética radical. Los recursos técnicos, grabado de linóleum, fotomontaje y serigrafía, principalmente, sirven en la reproducción de imágenes diáfanas que atraparon "momentos de la realidad social circunstanciada". Si bien, se van a producir en un espacio temporal, van a ser parte sustancial de la realidad contemporánea de México. Un fenómeno concomitante donde la sociedad civil, va a enfrentar a la sociedad política evidenciando su ruptura, su separación y las contradicciones históricas de un sistema hegemónico envejecido por su dictadura de partido, y la postmodernidad representada por estudiantes, obreros e intelectuales urbanos de la Ciudad de México.

La Gráfica del 68, revela también el antagonismo entre los dos contendientes, entre discursos oficiales y la subversión urbana callejera, que sacaron a la superficie el perfil de los actores sociales confrontados.

La escritura Gráfica del 68 lleva la impronta de la rapidez y lo presuroso del trazo, un cierto nerviosismo que aprovecha los accidentes conducidos del informalismo pictórico. Figuración 
impresionista que deja la sensación de ser dibujos que nunca se terminaron. La importancia de la Gráfica del 68, suma estas cualidades, el que fue un trabajo colectivo en el que participan diferentes actores, de diferentes instituciones, lo que le da su fuerza de creación anónima, y de ilustración de una época tan importante para los movimientos sociales urbanos de México.

En la Gráfica visual del 68 no hubo consignas partidistas, ni demandas del C.N.H., ni de la junta de intelectuales, ni de ningún otro tipo. Fue un trabajo colectivo, espontáneo, donde los actores sociales del movimiento estudiantil, fueron también los artistas, que crearon estas imágenes: los volantes, las pegas, los afiches, apenas se terminaban se repartían en la calle, se pegaban en los autobuses y comercios. Esta tarea no conocía de fatigas, ni de hambres, y se trabajaba día y noche.

El financiamiento de la Gráfica del 68 tiene otro aspecto importante. Pasadas las primeras semanas el papel y los materiales, con que la escuela contaba, se agotaron. Sólo quedaba el boteo, dinero recogido en las calles, que sí contaba con el apoyo masivo, lo recolectado no sólo alcanzaba para la compra de los materiales, sino que además alimentaba a decenas de estudiantes entregados al trabajo colectivo. Esto ocasionó que lo que se pintaba y escribía no estuviera condicionado, permitiendo una absoluta libertad creativa, libertad expresiva que se ajustaba nítidamente a los ideales que perseguían los estudiantes movilizados por su pliego petitorio. Esta acción solidaria, ese primer contacto cómplice y solidario, aunque oculto, que los habitantes de la ciudad ofrecían al movimiento estudiantil.

El financiamiento del pueblo, dinero que se recogía con el boteo, hacía posible parte sustancial de la producción gráfica de 1968. En esta doble acción se hospedaban valores concatenados. Unido a su importancia y repercusión en los ciudadanos, aunque se contrarrestaba en parte la propaganda oficial, también servía para que la ciudad en general viera en la gráfica una parte festiva, una parte original, una parte distinta de hacer propaganda política. Distinta a los medios usados por el régimen en el poder.

El Estado comprendió, justo a tiempo, la importancia que cobraba la imagen de la Gráfica del 68, como sucedánea del conflicto estudiantil. Lo comprendió y lo destruyó cuando envió a la imprenta de San Carlos, y a los talleres donde se producían estas imágenes certeras, estos testimonios geniales de la historia política de México, un grupo paramilitar que destruyó y acabó con todos los utensilios técnicos que se requerían para su diseño.

Con especial celo guardábamos copias de cada uno de los grabados producidos, y se iban acumulando en ese salón nunca antes tan activo de la Sociedad de Alumnos de San Carlos, los emisarios del régimen robaron la única posibilidad de contar con la colección completa.

Hay una secuencia de gráficas que aluden a La Libertad de Presos Políticos, llevan retratos de Vallejo, Campa, de estudiantes anónimos, etcétera. Casi siempre están detrás de una reja, o bien, hay uno que lleva una huella digital en el primer plano, alusión ingeniosa de ese pánico de los años 60 , que se generaliza entre estudiantes y profesores que fue el de quedar fichado. Esta síntesis 
visual, categórica que se logra en la gráfica del 68 revela lo injusto del hombre encarcelado por defender sus ideas. Los rostros son fantasmas o niños, estudiantes; son sombras dramatizadas, son huellas.

Rejas y cadenas, rostros que vimos constantes en la lucha de los jóvenes por liberar a los presos políticos, lucha que no surgió, en el conflicto del 68, ni por consignas de las izquierdas, ni por los anteriores arrestos a los líderes más conocidos de los movimientos obreros. Creo que el primer contacto que tuvimos en San Carlos con los presos políticos fue la noticia del encarcelamiento de Rico Galán que, el maestro Mario Moreno Capdevila, nos contaba visitaba en la cárcel; y por Enrique Condés Lara y Mario Rechi, que fueron acusados del bombazo a la Embajada de Bolivia que protestaba por la muerte del Che. El explosivo fue puesto de noche, asegurados de que no había personal en la misión, pero la policía descubrió el hecho y, por su propia torpeza, al trasladar la bomba hizo explosión y resultaron heridos algunos guardias.

José Revueltas ya conocía el encarcelamiento varias veces, sobre esas experiencias escribía y contaba su vida en la cárcel; y más que nada la vida de un disidente encarcelado, por sus ideales políticos y culturales. Sabíamos con horror de la feracidad de los carceleros, y el hacinamiento de los encarcelados.

El artista anónimo que reproducía los carteles, en los que se hacía referencia a los presos políticos, no recibió ninguna consigna para el diseño de esas imágenes, las conocíamos de antemano, y cuando Díaz Ordaz, en su informe de gobierno, declaró que no había presos políticos en las cárceles, confirmábamos la farsa, el teatro, el escándalo.

Por otro lado, no hay muchos mexicanos que puedan demostrar que en México existe justicia para el desposeído. El poder judicial defiende sólo los intereses de los poderosos; y los obreros, los campesinos, los empleados, los pequeños propietarios, los intelectuales y los artistas saben que es inútil buscar justicia en los tribunales.

¿Por qué visitábamos a nuestros presos políticos antes del conflicto del 68, y después del 68 en la crujía M del Palacio Negro? ¿Por un problema de conciencia? ¿Solidaridad humana? ¿Por convicciones políticas? ¿O por compartir los ideales de los presos? Creo que por una mezcla de todo esto, pero además porque en el fondo de nosotros mismos, y encima de nosotros mismos, veíamos suspendida el hacha del verdugo, pues éramos disidentes de la realidad social que sustentaba la reproducción de nuestra existencia material, de nuestra existencia cotidiana, y nos amenazaba el delito de disolución social, tipificado en el artículo 145, y 145 bis.

La sección de carteles que se refieren al deslinde de responsabilidades, la desaparición de los cuerpos de granaderos, la destitución de los responsables de los ataques policíacos; Gueto, Mendiola y Cerecero, fueron producidos en medio, a la mitad de la brutal represión de que fueron objeto los estudiantes. Las imágenes de los gorilas, masacrando adolescentes, no fueron imágenes estimuladas por los sueños, fue la realidad contundente, era la respuesta del régimen a una movilización del colectivo, de una parte de la población joven y estudiantil que exigía se cumplieran los principios del Estado de Derecho, que implicaba un régimen civil, y el respeto a la autonomía universitaria. 

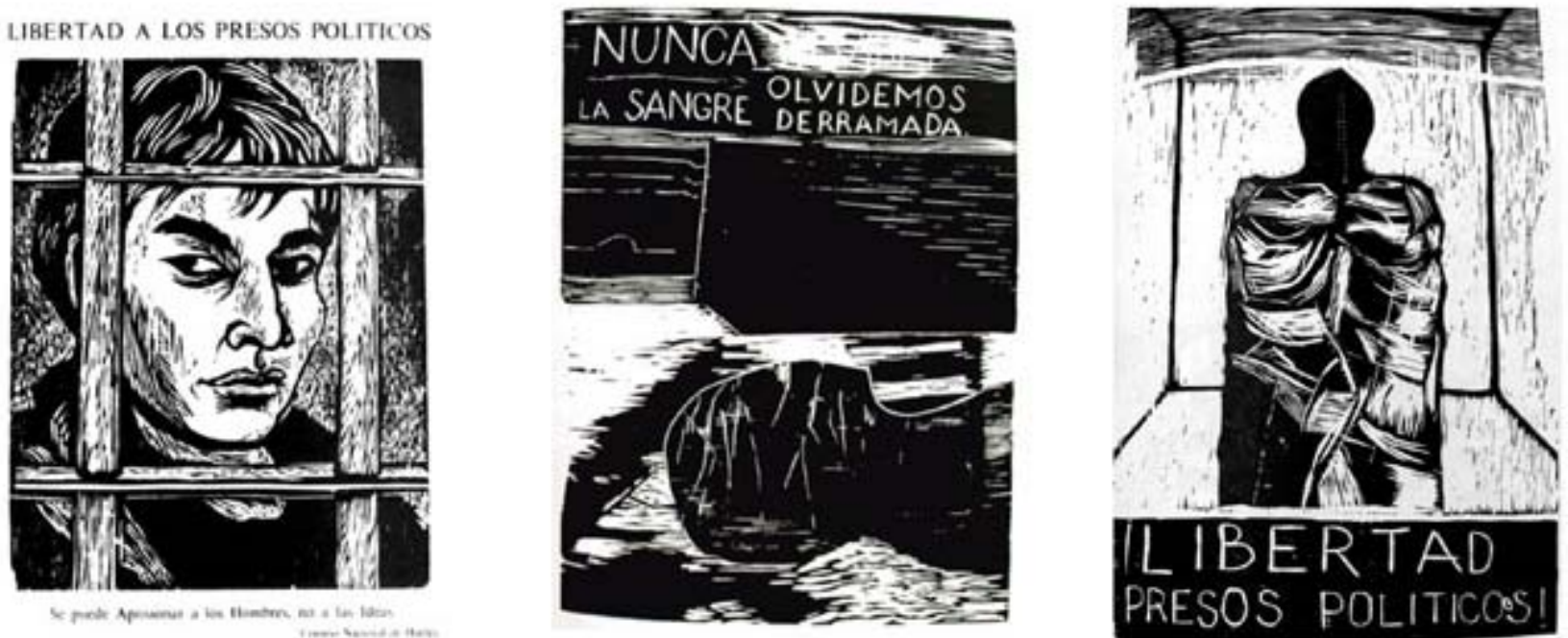

Esta serie sobre la represión es más dramática que L'Tableaux noir, de Goya. Son únicos por su fuerza y conmovedores por lo que dicen, por ser imágenes capturadas nítidamente de la realidad, y aquí se hospeda la parte básica, valorativa de Gráfica 68. Aquí estriba su aporte esencial, denunciar la brutalidad de un estado de derecho obstinado en no querer comprender los verdaderos móviles morales del movimiento estudiantil, cuyos ideales se iban enardeciendo, enalteciendo a la medida en que el régimen los intentaba sofocar.

Lección que el Estado no supo aprovechar, en ese momento; vio conspiración internacional donde sólo había tímida revuelta anarquista (falta de guía teórica); vio intentos amenazadores en contra de la estabilidad del gobierno, donde sólo había ideales renovadores y democratizantes; intentos por contemporizar con el mundo que nos llegaba de más allá de la mar salobre. El régimen, al sentirse amenazado en su estabilidad institucional, pudo mantener el statu quo con la fuerza de las armas, la masacre, la violencia; y, aún peor, recurrió a la corrupción de los líderes del movimiento.

Unas manos llevan la paloma de la paz, es el cartel dedicado al diálogo público solicitado en el mismo pliego petitorio. El diálogo es el único camino. Los jóvenes del 68 estaban conscientes de la necesidad de un diálogo abierto, no querían negociaciones en secreto; en otro cartel, unos estudiantes hablan con otros (estudiantes y gobierno), pero no a puerta cerrada, con representantes como lo solicitaba el régimen en el poder. Se solicitaba una discusión abierta y pública para dirimir las diferencias, como símbolo esencial de un nuevo diálogo con el gobierno que, además, debía reproducirse por la televisión y el radio. Sin embargo, al principio de autoridad, el otro, el autocrático, no se le puede sugerir como, ni dónde, ni a qué hora pueden efectuarse las negociaciones. Pues, el que manda dicta las normas y las formas, no negocia, ordena, hace edictos $y$, en caso necesario, ordenará el uso de las armas para que se cumplan los mandatos. Y la sociedad civil, los ciudadanos, no tenían derecho a imponer los formatos del diálogo como una petición concreta a la sociedad política de ese tiempo.

Todo es posible en la paz, Conozca México, etcétera, fueron los eslóganes en la preparación de la Olimpiada del 68, que los hicieron coincidir con los símbolos de la represión, las armas, los tanques, los soldados... Visitante quieres conocer México. Visita las cárceles. 

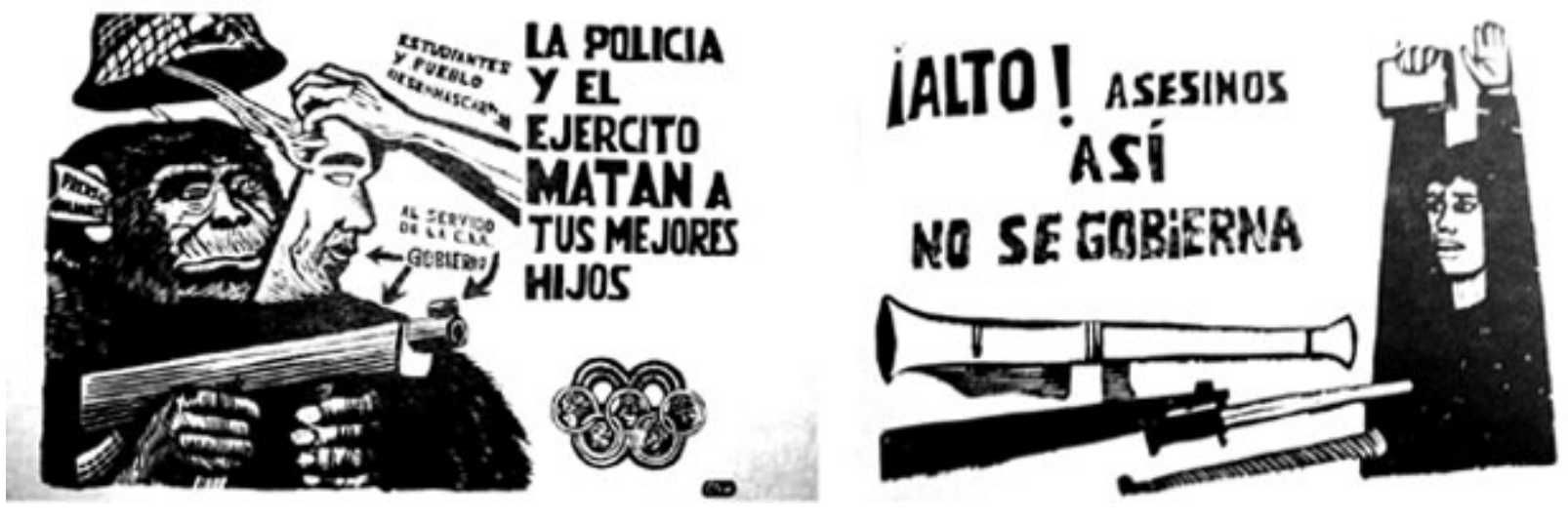

\title{
Conclusión
}

Como apuntábamos al inicio de este ensayo, la Gráfica del 68 es un acervo histórico visual del primer gran movimiento social y urbano de la Ciudad de México, construido por una serie de carteles, pegas-stickers y volantes, mantas, pancartas, grabados, que fueron elaborados principalmente por los estudiantes de la Escuela Nacional de Artes Plásticas (ENAP), hoy Facultad de Diseño y Arte de la UNAM, en el que también participaron alumnos de la Escuela Nacional de Pintura y Escultura La Esmeralda, el IPN, Chapingo, entre otros.

\begin{abstract}
Al ir más allá de la traslación inmediatista, entre contingencia política y resistencia artística que demandaba la cultura militante, el arte de la Avanzada supo dar el giro - deconstructivo- que le permitió pasar de un arte de crítica al poder-en-representación (la dictadura) a la crítica de las representaciones-de-poder, es decir, al análisis y desmontaje de todas aquellas codificaciones autoritarias y represivas hechas sistema y orden, enunciados y comunicación. A ese arte de la Avanzada podríamos llamarlo un arte político-crítico: un arte que desafía las tramas de poder y dominancia ideológico-sociales y culturales, generando alternativas de sentido en las brechas e intervalos del sistema hegemónico. Un arte, el de la Avanzada, que mezcló el filo de la denuncia social con experimentaciones de signos y conceptos suficientemente audaces como para renovar la conciencia del lenguaje mismo, del lenguaje artístico, como una zona intensiva de choques y disparos de la significación ${ }^{3}$.
\end{abstract}

La coincidencia en la celebración de las Olimpiadas en México y el conflicto estudiantil hizo, entre otros al régimen en el poder, aniquilar el movimiento social juvenil urbano, recurriendo al medio desesperado del crimen de Estado. Intereses multimillonarios estaban en juego. La imagen del México moderno se desmoronaba ante el crédito fiduciario internacional. En caso de fracasar la Olimpiada, también fracasaba toda la imagen del México moderno, el milagro mexicano y sus postulados económicos desarrollistas. Como medida desesperada el régimen culminó su actuación y su diálogo con este movimiento social, recurriendo a la matanza del 2 de octubre.

Los carteles que aluden al 2 de octubre son sangrientos. Las líneas parecen haber sido dibujadas por manos que temblaban, informes, sin seguridad, frases escuetas acompañan estos diseños llenos de sangre: No claudicamos; Tlatelolco 68; 2 de octubre; Ni un momento más de rodillas; Asesinos; Nunca olvidaremos, La lucha continúa.

La lectura de estos carteles es dolorosa, las fábricas de edición van a ser plenamente clandestinas, ahí donde antes había talleres libres no se puede producir más, ni siquiera asomar la cara por las 
ventanas. El movimiento social urbano de los estudiantes mexicanos es aplastado de golpe. Sólo quedan los muertos, los encarcelados, el clandestinaje, las paranoias, la huida, el destierro, el encierro, la frustración, y el movimiento guerrilleril desesperado.

Algunas voces de aliento como las de don Jesús Silva Herzog, Octavio Paz o Guillermo Massieu, etcétera, no sirven de nada. Las familias de los estudiantes entierran a sus muertos. Creíamos que éramos miles y sólo fuimos unos cuantos cientos de estudiantes. No hubo una respuesta al diálogo público. Desolación, silencio, justificaciones de la prensa que trata de minimizar los hechos. La vuelta a clases, el inicio de las Olimpiadas del 68.
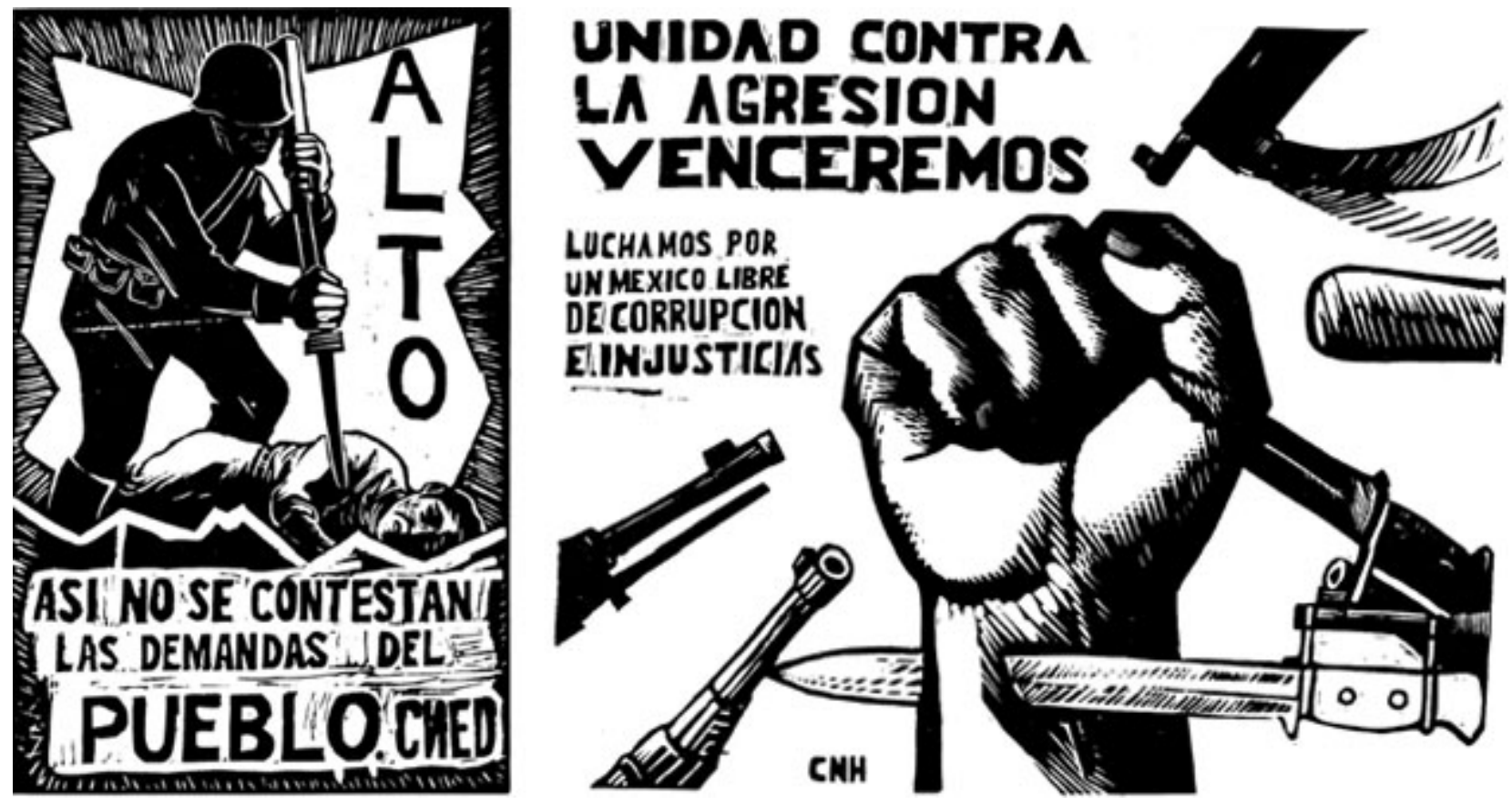

${ }^{1}$ Disponible: http://es.wikipedia.org/wiki/Taller_de_Gr\%C3\%A1fica_Popular (22.02.2015).

${ }^{2}$ Ver en provecho: Arriola, Carlos, El Movimiento Estudiantil Mexicano en la Prensa Francesa, Colegio de México, México, DF 1979, p. 43.

${ }^{3}$ Disponible: http://hemisphericinstitute.org/hemi/es/e-misferica-62/richard (22.02.15).

\section{BIBLIOGRAFÍA}

Anónimo, El Móndrigo. Bitácora del Consejo Nacional de Huelga, Alba Roja S.C.L, 2ª ed., México D.F. s.d. Arriola, Carlos, El Movimiento Estudiantil Mexicano en la Prensa Francesa, Colegio de México, México D.F. 1979 Campa, Valentín, Mi testimonio: Memorias de un comunista mexicano, Cultura Popular, México D.F. 1981. González de Alba, Luis, Los días y los años, Era, México D.F. 1972. Macías Báez, Eduardo, Fundación e historia de la academia de San Carlos, Mexicana, México D.F. 1974. Marcuse, Herbert, La dimensión esthétique, Du Seuil, Paris 1979.

Mendieta y Nuñez, Lucio, Sociología del Arte, UNAM, México D.F. 1972.

Monsiváis, Carlos, 19766, Días de guardar, Era, México D.F. 1976.

Revueltas, José, Consideraciones sobre la autogestión académica, Anteo, México D.F. 1969.

Revueltas, José, México 68: Juventud y Revolución, Era, México D.F. 1981. 
Revueltas, José/VALLE, Eduardo/Álvarez, Raúl, Tiempo de hablar. Los procesos de México 68, México D.F. 1970.

Sánchez Vázquez, Adolfo, Estética y Marxismo, 2 vols., Era, México D.F. 1984.

Toberg, Friedrich, Estética política, Villalar, Madrid 1977.

Wences Reza, Rosalío, El movimiento estudiantil y los problemas nacionales. México, Nuestro Tiempo, México D.F. 1971.

\section{REFERENCIAS ELECTRÓNICAS}

http://es.wikipedia.org/wiki/Taller_de_Gr\%C3\%A1fica_Popular (22.02.15)

http://hemisphericinstitute.org/hemi/es/e-misferica-62/richard (22.02.15)

\section{IMÁGENES}

Copyright responsabilidad del autor.

Revista internacional de investigación, innovación y desarrollo en Diseño • ISSN 1889-433 x

Grupo de investigación Lenguaje Visual y Diseño Aplicado • Plan Andaluz de Investigación • E. Politécnica S. • Universidad de Málaga 